\title{
The Interaction Between the Expression of Proliferative Biomarkers and Clinical Characteristics in Breast Cancer
}

DOI: 10.30699/acadpub.mci.2.2.20

Submitted: 17 January 2018

Revised: 10 March 2018

Accepted: 20 March 2018

e-Published: 1 April 2018

\section{Keywords:}

Breast Cancer

Clinical Utility

Clinicopathological

Aspects

Proliferative Biomarkers

RT-PCR
Sepideh Mansouri ${ }^{1, \#, ~ R e z v a n ~ E s m a e i l i ~}{ }^{2, \#, ~ A h m a d ~ K a v i a n i ~}{ }^{3}$, Mahdi Rezaei $^{2,4}$, Nasrin Abdoli ${ }^{2}$, Parisa Mokhtari-Hesari ${ }^{5}$, Leila Farahmand ${ }^{1}$, Keivan Majidzadeh-A, ${ }^{2, *}$

${ }^{1}$ Recombinant Proteins Department, Breast Cancer Research Center, Motamed Cancer Institute, ACECR, Tehran, Iran

${ }^{2}$ Genetics Department, Breast Cancer Research Center, Motamed Cancer Institute, ACECR, Tehran, Iran

${ }^{3}$ Department of Surgery, Tehran University of Medical Sciences, Tehran, Iran

${ }^{4}$ Seed and Certification and Registration Institute, Karaj, Iran

${ }^{5}$ Integrative Oncology Department, Breast Cancer Research Center, Motamed Cancer Institute, ACECR, Tehran, Iran

* Corresponding author: Keivan Majidzadeh-A, Genetics Department, Breast Cancer Research Center, Motamed Cancer Institute, ACECR, Tehran, Iran.

E-mail: Kmajidzadeh@razi.tums.ac.ir

\# They are co first author and contributed to the work equally.

\section{Abstract}

Introduction: Proliferation of cancer cells and the potential of metastasis depend on the activity of different biomarkers such as proliferative ones. Proliferative biomarkers including ki-67, cyclin E1, cyclin D1, p27, and p21 were analyzed through immunohistochemistry (IHC) in previous studies. Methods: The current study aimed at investigating the utilizing role of RT-PCR in studying proliferative biomarkers including Ki-67, Cyclin E1, Cyclin D1, P27, and $P 21$ to figure out the association between proliferative biomarkers and clinical aspects in patients with early breast cancer. One hundred and twenty-three patients with primary breast cancer were entered in the current study. Patients' clinicopathological characteristics were obtained and also expressions of the proliferative biomarkers were investigated through RT-PCR on both cancerous and normal adjacent breast tissue.

Results: It was observed that in contrast to Cyclin $D$ and $P 27$, expression of $\mathrm{Ki}-67$, $C y c l i n E$, and $P 21$ were higher in tumor samples compared with normal adjacent tissue. In addition, Cyclin $D$ was higher in $E R / P R$ positive and $H E R 2$ negative tumors and it was also higher in greater tumor size. Similarly, Cyclin E expression was higher in greater tumor size. Furthermore, patients with higher expression of $P 27$ experienced worse prognosis.

Conclusions: Studying the proliferative biomarkers via a quantitative and automated method in Iranian patients showed that proliferative biomarkers had correlations with clinical aspects. Further studies to analyze the clinical utility of proliferative biomarkers in greater populations are warranted. 


\section{INTRODUCTION}

Development of a neoplasia and the potential of metastasis depend on the activity of many biomarker groups such as growth receptors, cytosolic growth cascade, and cellular proliferative biomarkers etc. Proliferative biomarkers act as accelerators or inhibitors of cell cycle, which consists of $K i-67, C d k$ inhibitors (p21 $1^{\text {WAFI/CIPI }}$ and p27), Cyclin E1, Cyclin D1, etc. The roles of proliferative biomarkers in cell proliferation were investigated in many studies [1].Ki67 is the main member of this group, the expression of which is increased during normal mitosis [2].Also the relationship between its IHC based expression analysis and histopathological aspects of cancer such as tumor grade, tumor size, and hormone receptor status was previously studied, although the results were controversial [3]. The expression of Cyclin $E 1$ and D1 increases in breast cancers [4-6]. Overexpression of Cyclin D is related to the expression of estrogen/progesterone receptors in breast cancer [7]. Also, overexpression of Cyclin E1 is accompanied by a higher grade of tumor and tumor size [8]. The P27 and P21 belong to cyclin dependent kinase inhibitors (CDKIs) or kinase inhibitory protein (KIP). CDKIs act as cell cycle inhibitors. They link to cyclin D1-CDK and transfer cyclin D1-CDK to the nucleus, which makes cyclin D1-CDK inactive [3]. Many studies reveal that $P 21$ expression is reduced in tumor cells in comparison with normal tissue $[4,9]$. Many reports suggest application of proliferative biomarkers in patients' management such as estimation of survival and prognosis [8, 10-12]. Former studies showed some correlations between the expression of biomarkers investigated almost through IHC and histological characteristics $[8,12]$. The current study aimed at comparing gene expression in Iranian patients through real-time PCR and seeking the relationship between the expression of proliferative biomarkers as well as the histopathological aspects.

\section{METHODS}

\section{Study Population}

Eligibility of 123 patients was assessed; 10 patients were excluded due to incomplete clinicopathologic data. Two hundred and forty-six breast tissue samples from 123 patients with primary breast cancer including 123 tumor samples and 123 normal adjacent tissue samples were included in the current study.

Samples were received from Breast Cancer Research Center Biobank (BCRC-BB). According to the protocols followed by BCRC-BB, immediately after excisional biopsy or surgery, sample tissue was snap-frozen in liquid nitrogen and stored at $-70^{\circ} \mathrm{C}$. $\mathrm{BCRC}-\mathrm{BB}$ is obliged to ethical guidelines and recommendations for Biobanks on the storage and use of human biological samples [13]. The current project was previously approved by the Ethics Committee of the Breast Cancer Research Center (BCRC). Normal adjacent RNAs were used for normalization. Clinical data were gathered in BCRC based on Patients' information consisted of surgical and pathological information from 2008 to 2013.

\section{Gene Expression Assay}

Primers and TaqMan probes were designed by Gene Runner Software version 3.0.5 for KI67, CCNB1, $C C N A 1, C C N E 1$, and $C C N D 1$. The list of primers and probes are in Table 1. ACTB and TFRC were used as housekeeping genes [14].

RNA extraction was performed using 8-20 $\mathrm{mg}$ of breast tumor and normal adjacent tissue by Rnx plus (Cinagen, Iran) as previously explained [14]. The quality and quantity of extracted RNA were measured by gel electrophoresis and spectrophotometry, respectively. Synthesis of cDNA was performed using cDNA synthesis kit (Qiagen, Germany) according to the manufacturer's protocol.

Real-time data acquired through 7500 software version 2.0.6. $\triangle \mathrm{CT}$ (biomarker gene expression minus housekeeping expression) were considered as biomarkers expression. Gene expression analysis was conducted using $\Delta \Delta \mathrm{CT}$ method. Normal adjacent tissue was used as the control sample. Categorization was performed according to the cut off values for $\Delta \Delta \mathrm{CT}$ above -0.5 as lower expression and under -0.5 as overexpression.

\section{Statistical Analysis}

To assess the differences of biomarkers expression between tumor and normal adjacent tissue, the paired samples $\mathrm{t}$ test was conducted on the $\Delta \Delta \mathrm{CT}$ measure. Patients were categorized into two groups based on low and high biomarker expression. Optimal cutoff to identify low expression and high expression of each biomarker was selected based on the biological data. The clinicopathological variables were categorized into two groups. Non-parametric Mann-Whitney $U$ test was administered to compare the mean of biomarkers expression in two different groups of clinicopathological variables. Then, the correlation between grouped biomarkers and clinicopathologi- 
cal variables were analyzed through chi-square test and the correlation coefficient was considered. Survival analysis was performed to analyze patients' overall survival. In order to find overall survival, the Kaplan-Meier estimator was used. The correlation between grouped biomarkers and survival rate were analyzed through the Cox-proportional hazards regression model. Statistical analyses were done with SPSS version 16, JMP SAS (SAS Institute, Cary, NC, USA), and Graph Pad Prism (Version 5.04; Graph Pad Software Inc., La Jolla, CA, USA) software.

\section{RESULTS}

A total of 123 patients with primary breast cancer were entered in the current cohort. Patients' mean age was $47.3 \pm 15.6$ years. All specimens were obtained prior to any systemic therapy. The median follow-up time was 38 months (confidence interval (CI) $95 \%=5-84$ months). Histopathological aspects including histologic grade, tumor size, hormone receptor (HR) status, HER2 status, and patients' general health status (with or without event) were investigated and their relationship with biomarkers expression was studied. Table 2 summarizes the patients' characteristics.

\section{Biomarkers Expression}

As mentioned before, biomarkers expression was measured through RT-PCR. Analysis of the expression revealed that $\mathrm{Ki}-67, \mathrm{Cyclin} \mathrm{E}$, and $\mathrm{P} 21$ were highly expressed in tumor samples compared with normal tissue $(\mathrm{P}=0.03,0.00$, and 0.01 , respectively). In contrast, Cyclin D1, and P27 expression decreased in tumor samples $(\mathrm{P}=0.00$ and 0.044 , respectively). When the expression of biomarkers was categorized into two groups of low and high, higher expression of $\mathrm{Ki}-67$, Cyclin E, and $\mathrm{P} 21$ was noted in $83(67.5 \%), 55(52.9 \%)$, and $80(65 \%)$ patients and lower expression of $P 27$, and Cyclin D1 was observed in $93(75.6 \%)$, and $90(73.2 \%)$ of patients, respectively.

\section{The Correlation Between Biomarkers Expression and Clinicopathological Variables}

The difference of mean expression of each biomarker was assessed in different groups of clinicopathological variables using non-parametric the Mann-Whitney $\mathrm{U}$ test. It was shown that the expression of $P 21$, $K i-67$, Cyclin D, and $P 27$ was higher in high grade tumors, whereas the expression of Cyclin $E$ was lower in high grade tumors. In addition, the expression of $\mathrm{Ki}-67, \mathrm{P27}$, and Cyclin $D$ were higher in $E R / P R$ positive tumors, the expression of $P 21$ and Cyclin $E$ were higher in $E R / P R$ negative tumors though. Analyzing the expression of biomarkers in the two groups of tumor size revealed high expression of all biomarkers in larger tumors. Finally, the expression of biomarkers except $\mathrm{Ki}-67$ was lower in HER2 positive tumors. Although, a plenty of these results were not statistically significant, the differences between the expression of Cylcin D in $H R$ positive/negative, HER 2 positive/negative, and T1/T2 were significant $(\mathrm{P}=0.04,0.03$, and 0.01 , respectively). Furthermore, the expression of cyclin $\mathrm{E}$ in larger tumors was more than tumors $<2 \mathrm{~cm}(\mathrm{P}=0.02)$.

In the next step, each biomarker expression was categorized into two groups of low and high expression. It was observed that higher expression of Cyclin $D$ was correlated with $E R / P R$ positivity $(H R 3.07, \mathrm{P}=$ 0.02 ). In contrast, there was a negative association between Cyclin $D$ expression and HER2 positivity (HR 0.17, $\mathrm{P}=0.00$ ).

Investigating the correlations between biomarkers expression revealed a positive correlation between Cyclin D and P27 (HR 3.41, $\mathrm{P}=0.01$ ), and also between Ki-67 and Cyclin E (HR 2.86, $\mathrm{P}=0.02$ ). Analyses of other biomarkers expression did not show any correlations.

\section{Survival Analysis}

The mean follow-up duration was 38 months $(\mathrm{CI} 95 \%=8-64$ months). Overall survival was estimated about $81 \%$ and $50 \%$ at 36 and 60 months follow-up, respectively. All clinical and histopathological factors (histological grading, tumor size, $E R /$ $P R$, and HER2 status) and also biomarkers were evaluated for their prognostic values in univariable analyses for overall survival (OS). Analyses of survival rate using the Kaplan-Meier test elucidated that tumors with high expression of p27 experienced worse prognosis $(\mathrm{P}=0.049)$. Although there were differences between survival rates in patients in regard to expression of Ki-67, Cyclin D, Cyclin E, and $P 21$, none of the variables had statistically significant correlation with survival. Table 3 summarizes the grouped biomarkers frequencies and prognostic impacts of biomarkers in univariable analysis. Figure 1 shows the survival curves based on biomarkers expression. 


\section{A: $\mathbf{P 2 7}$}

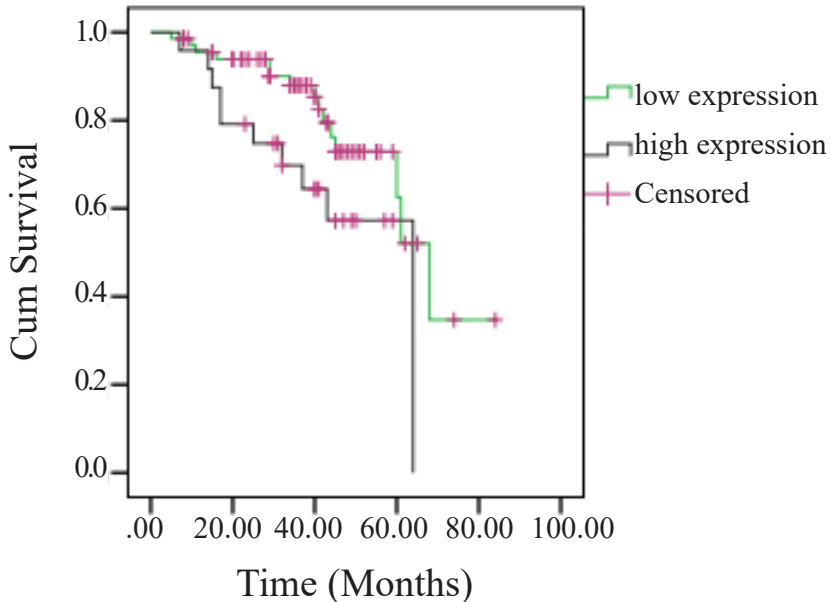

\section{B: Cyclin E}

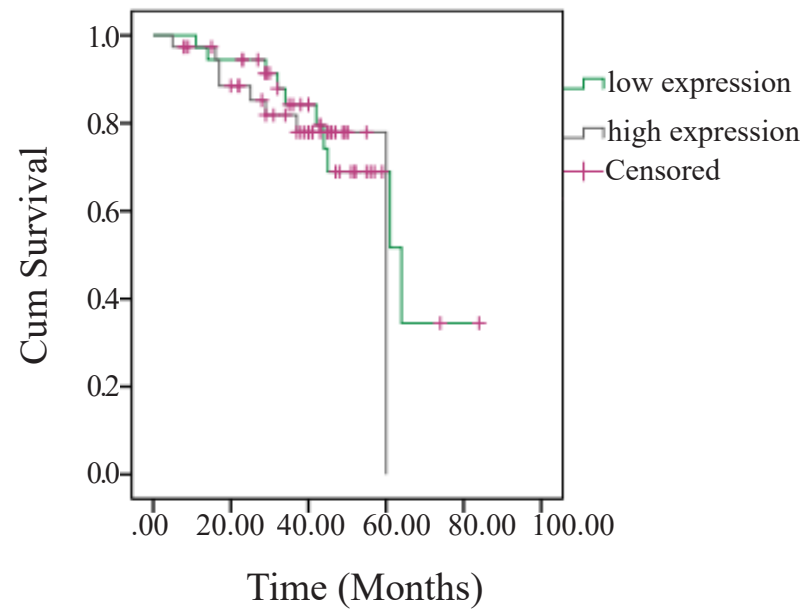

\section{C: $\mathbf{P} 21$}

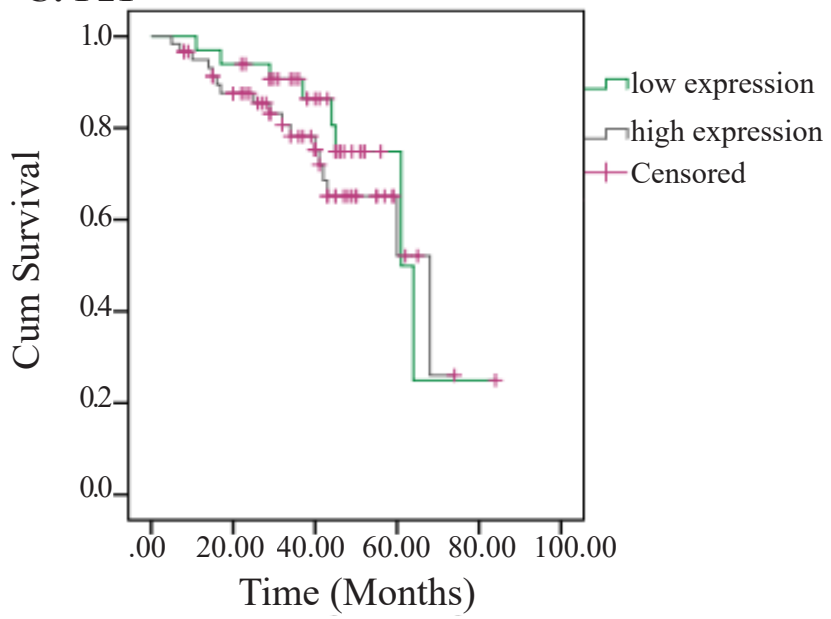

D: Ki67

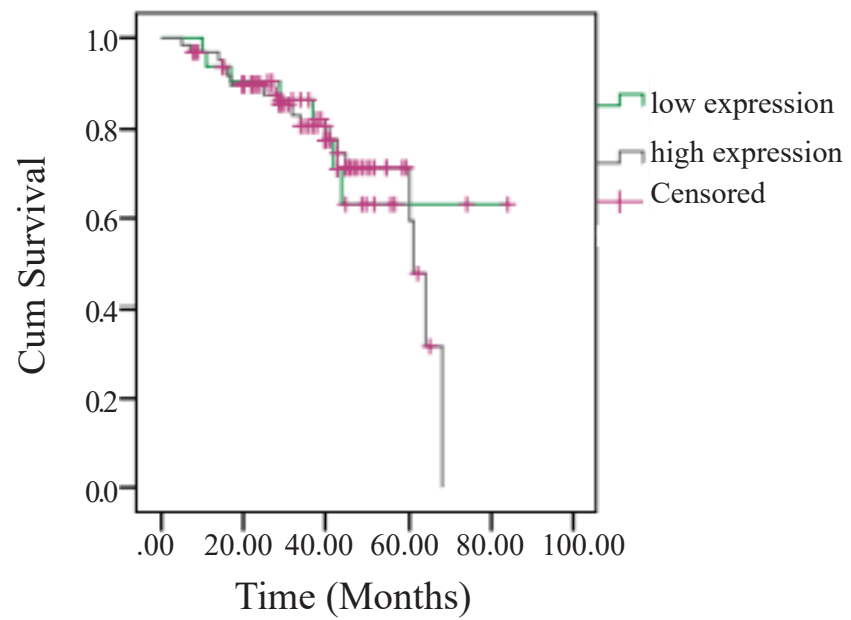

\section{E: Cyclin D}

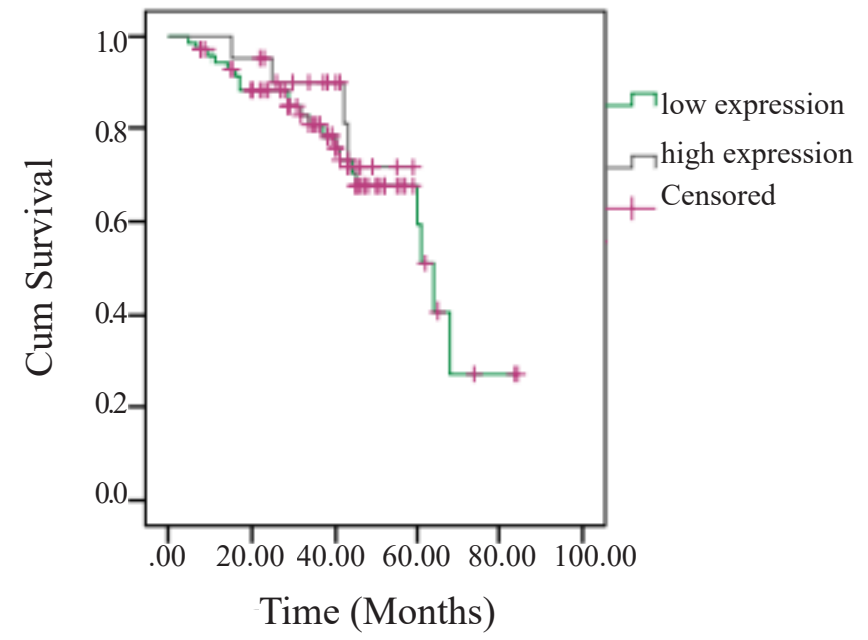

Figure 1: The Kaplan-Meier Survival Curves; as shown in A: $P 27$ overexpression associates with worse prognosis. Overall survival did not differ in overexpressed biomarkers including B: Cyclin E, C: P21, D: Ki-67, and E: Cyclin D 


\section{DISCUSSION}

Since systemic therapy is a double-edged sword, many studies are conducted to determine the best predictive and prognostic biomarkers to maximize the benefits of systemic therapy and minimize the adverse effects. Cell activity of proliferative biomarkers contributes to the development of neoplasia and metastasis. In the current study, proliferative biomarkers consisted of $\mathrm{Ki}-67$ and $C d k$ inhibitors (P21 WAFICIPI and P27), Cyclin E1 and Cyclin D1 were investigated. Many reports suggest the application of proliferative biomarkers to predict the clinical aspects of patients including survival and prognosis. Some reports studied the proliferative biomarkers through IHC, a semi quantitative method $[8,10,11$, 15].

Analyzing the expression of biomarkers via RT-PCR has some benefits such as high sensitivity and specificity contrary to studying through IHC. RT-PCR is applicable in most laboratories. It is less time-consuming and as a consequence there is an opportunity to study a large number of samples simultaneously. Since IHC is a manual method, its accuracy relies on expertise. There is an unavoidable variability between the results of studying biomarkers through IHC. On the other hand, RT-PCR is an automated method to study biomarkers quantitatively and more accurately applied in a few studies. Since analyzing biomarkers expression through RT-PCR was not formerly investigated in Iranian patients with breast cancer, the current study was conducted.

Similar to previous studies, analysis of the expression of biomarkers through RT-PCR revealed that Ki-67, Cyclin E1, and P21 expressions [16-20] were higher in tumor samples [15] and Cyclin D1 and $P 27$ expression decreased in tumor samples [3]. In contrast, some studies on the expression biomarkers through gene expression assays revealed that $P 21$ expression was lower and Cyclin D1 was higher in tumor tissue $[4,9]$.

Analysis of the association between biomarker expression and histopathological aspects revealed a positive association between cyclin $\mathrm{D}$ and ER/PR and also between cyclin E and HER2 status. In addition, there was a positive correlation between cyclin D and p27 and also between Ki-67 and cyclin E. On the other hand, a negative correlation was observed between cyclin D and HER2 status. The study of cyclin D1 both through IHC and RT-PCR revealed the same correlation between cyclin D1 and ER/PR status in previous studies [7, 21, 22]. Since Cyclin D1 expression was induced by ER, a positive correlation between Cyclin DI and ER was estimated
[23]. Also, the positive correlation between Cyclin $D 1$ expression and $P 27$ was observed in similar studies [21, 22]. In a study by Hermeking $\mathrm{H}$ et al., on cyclin D1, cyclin E1, p21, and p27 expression in cancer cell-lines through Western blot, it was observed that estradiol treatment increased the amount of p21, p27, and cyclin E, which depended on cyclin D1 expression [24]. It was concluded that the overexpression of Cyclins DI and E1 is estrogen-dependent. Similar to the current study, analyzing biomarkers expression via IHC found no significant correlation between cyclin D1 and grade of tumor [25]. Furthermore, the positive correlation between the expression of cyclin E and Ki-67 studied through chromogenic in situ hybridization (CISH) was observed in a similar study [26]. Similar to the current study results on the association between Ki67 and histopathologic variables, some studies did not observe any associations between Ki67 expression (assessed through either RT-PCR or IHC) and histopathologic aspects [8]. Despite previous studies investigating the correlation between tumor size and $\mathrm{Ki}-67$ ( assessed through either RT-PCR [15] or IHC) [3], and correlation of ER status and grade of tumor with $\mathrm{Ki}$ $67[2,17,27,28]$, the current study did not show any correlations between $\mathrm{Ki}-67$ and histopathological variables.

In addition, although there were many studies on the association of $P 27$ [29, 30], Cyclin E [21, 31], and $P 21$ with histopathological aspects $[20,32]$, the current study showed no correlation between $P 27$ and P21 with histopathological variables. However, Rudolph et al., similar to the current study, showed no correlation between Cyclin E and tumor size [11]. In the current study, 123 patients were followed up. Overall survival was estimated about $81 \%$ and $50 \%$ at 36 and 60 months follow-up, respectively. Although high expression of P27, Ki-67, Cyclin D, Cyclin E, and $P 21$ was associated with lower OS, $P 27$ was the only biomarker with statistically significant prognostic impact. Many studies showed that Ki-67 [33-36], P27 [37-40], P21 [32, 41-46], Cyclin DI [47-51], and Cyclin E1 [16, 52-54] have no any prognostic significance. In addition, some studies investigated biomarkers through RT-PCR and showed no prognostic impact for Cyclin D [55], Cyclin E $[54,55]$ and $P 27[55]$ in patients with breast cancer. In contrast, a meta-analysis on the prognostic impact of Ki-67 showed that studying ki-67 expression via IHC had prognostic value [10]. Also, the study by Rudolph et al., showed that the expression of Cyclin E1 had impacts on disease-specific survival (DSS) and metastasis-free survival (MFS) [11]. In addi- 
tion, analyzing Cyclin E through RT-PCR in another study revealed that higher expression of Cyclin $E$ correlated with better overall survival [56]. Since many studies implicated the prognostic significance of proliferative biomarkers [11, 20, 56-61] further studies can clarify the predictive role of proliferative biomarkers through RT-PCR in the survival of patients with breast cancer.

As there is a question on the usefulness of RT-PCR in studying proliferative biomarkers, the expression of Ki67, CCNE1, CCND1, CCN1B, and CCN1A encoding ki-67, cyclin E1, cyclin D1, p27 and p21, respectively, was studied through RT-PCR in the current study. It was observed that the expression of $\mathrm{Ki}-67$, Cyclin E, and $P 21$ was higher in tumor samples compared with the expression of Cyclin D and P27 that was lower in tumor samples. In addition, when the association of clinicopathological factors and biomarkers expression was analyzed, positive correlations were observed between cyclin $\mathrm{D}$ and $E R / P R$ and also between cyclin E and HER2 status. Analysis of the correlation between biomarkers expression showed a positive correlation between Cyclin $D$ and $P 27$ and also between Ki-67 and Cyclin E. On the other hand, there was a remarkable negative association between Cyclin D and HER2 status. Survival analysis highlighted that higher expression of $P 27$ was associated with lower overall survival. It can be concluded that investigating proliferative biomarkers through RT-PCR can have clinical utility in Iranian patients with breast cancer and further studies are needed to analyze them in greater populations.

\section{ACKNOWLEDGEMENTS}

This project was granted by ACECR No. 1828 .

\section{CONFLICT OF INTEREST}

The authors declared no conflict of interests regarding the publication of the paper.

\section{ETHICS APPROVAL}

This study was approved by the Ethics Committee of Motamed Cancer Institute.

\section{REFERENCES}

1. Colozza M, Azambuja E, Cardoso F, Sotiriou C, Larsimont D, Piccart MJ. Proliferative markers as prognostic and predictive tools in early breast cancer: where are we now? Ann Oncol. 2005;16(11):1723-39. https://doi.org/10.1093/annonc/mdi352 PMID:15980158

2. Urruticoechea A, Smith IE, Dowsett M. Proliferation marker $\mathrm{Ki}-67$ in early breast can- cer. J Clin Oncol. 2005;23(28):7212-20. https://doi.org/10.1200/JC0.2005.07.501 PMID:16192605

3. Khan AA, Abel PD, Chaudhary KS, Gulzar Z, Stamp GW, Lalani EN. Inverse correlation between high level expression of cyclin $\mathrm{E}$ and proliferation index in transitional cell carcinoma of the bladder. Mol Pathol. 2003;56(6):353-61. https://doi.org/10.1136/mp.56.6.353 PMID: 14645699 PMCID:PMC 1187355

4. $\mathrm{Hu}$ Y, Sun H, Drake J, Kittrell F, Abba MC, Deng L, et al. From mice to humans: identification of commonly deregulated genes in mammary cancer via comparative SAGE studies. Cancer Res. 2004;64(21):7748-55. https://doi.org/10.1158/0008-5472.CAN-04-1827 PMID:15520179 PMCid:PMC4170686

5. Madi L, Ochaion A, Rath-Wolfson L, Bar-Yehuda S, Erlanger A, Ohana G, et al. The A3 adenosine receptor is highly expressed in tumor versus normal cells: potential target for tumor growth inhibition. Clin Cancer Res. 2004;10(13):44729. PMID:15240539

6. Murray SA, Yang S, Demicco E, Ying H, Sherr DH, Hafer LJ, et al. Increased expression of MDM2, cyclin D1, and p27Kip1 in carcinogen-induced rat mammary tumors. J Cell Biochem. 2005;95(5):875-84. https://doi.org/10.1002/jcb.20414 PMID:15844214

7. Salimi M, Mozdarani H, Majidzadeh K. Expression pattern of ATM and cyclin D1 in ductal carcinoma, normal adjacent and normal breast tissues of Iranian breast cancer patients. Med Oncol. 2012;29(3):1502-9. https://doi.org/10.1007/s12032-011-0043-5 PMID:21850541

8. Mehdipour P, Pirouzpanah S, Sarafnejad A, Atri M, Shahrestani ST, Haidari M. Prognostic implication of $\mathrm{CDC} 25 \mathrm{~A}$ and cyclin E expression on primary breast cancer patients. Cell Biol Int. 2009;33(10):1050-6. https://doi.org/10.1016/j.cellbi.2009.06.016 PMID: 19555767

9. Zhao C, Meng L, Hu H, Wang X, Shi F, Wang $\mathrm{Y}$, et al. Spontaneously immortalised bovine mammary epithelial cells exhibit a distinct gene expression pattern from the breast cancer cells. BMC Cell Biol. 2010;11:82. https://doi.org/10.1186/1471-2121-11-82 PMID:20969773 PMCID:PMC2978144

10. de Azambuja E, Cardoso F, de Castro G, Jr., Colozza M, Mano MS, Durbecq V, et al. Ki67 as prognostic marker in early breast cancer: a meta-analysis of published studies involving 12,155 patients. Br J Cancer. 2007;96(10):150413.https://doi.org/10.1038/sj.bjc. 6603756 PMID:17453008 PMCID:PMC2359936

11. Rudolph P, Kuhling H, Alm P, Ferno M, Baldetorp 
B, Olsson $\mathrm{H}$, et al. Differential prognostic impact of the cyclins E and B in premenopausal and postmenopausal women with lymph node-negative breast cancer. Int J Cancer. 2003;105(5):674-80. https://doi.org/10.1002/ijc.11132 PMID: 12740917

12. Prihantono P, Hatta M, Binekada C, Sampepajung D, Haryasena H, Nelwan B, et al. Ki-67 Expression by Immunohistochemistry and Quantitative Real-Time Polymerase Chain Reaction as Predictor of Clinical Response to Neoadjuvant Chemotherapy in Locally Advanced Breast Cancer. Journal of Oncology.2017;2017:6209849. https://doi.org/10.1155/2017/6209849 PMID:29225623 PMCID:PMC5684548

13. Majidzadeh AK, Kaviani A, Esmaeili R, Farahmand L, Shojamoradi MH, Zare AA, et al. Iranian BreastCancerBio-Bank: theactivityandchallenging issues. Cell Tissue Bank. 2013;14(1):11-20. https://doi.org/10.1007/s10561-012-9293-5 PMID:22318652

14. Majidzadeh AK, Esmaeili R, Abdoli N. TFRC and ACTB as the best reference genes to quantify Urokinase Plasminogen Activator in breast cancer. BMC Res Notes. 2011;4:215. https://doi.org/10.1186/1756-0500-4-215 PMID:21702980 PMCID:PMC3141519

15. Yuan $\mathrm{P}, \mathrm{Xu} \mathrm{B}$, Wang C, Zhang C, Sun M, Yuan L. Ki-67 expression in luminal type breast cancer and its association with the clinicopathology of the cancer. Oncol Lett. 2016;11(3):2101-5. https://doi.org/10.3892/o1.2016.4199 PMID:26998129 PMCID:PMC4777879

16. Potemski P, Pluciennik E, Bednarek AK, Kusinska R, Jesionek-Kupnicka D, Pasz-Walczak G, et al. Cyclin E expression in operable breast cancer quantified using real-time RT-PCR: a comparative study with immunostaining. Japanese journal of clinical oncology. 2006;36(3):142-9. https://doi.org/10.1093/jjco/hyi246 PMID:16520356

17. Elkablawy MA, Albasri AM, Mohammed RA, Hussainy AS, Nouh MM, Alhujaily AS. Ki67 expression in breast cancer. Correlation with prognostic markers and clinicopathological parameters in Saudi patients. Saudi medical journal. 2016;37(2):137-41. https://doi.org/10.15537/smj.2016.2.12285 PMID:26837394 PMCID:PMC 4800910

18. Bortner DM, Rosenberg MP. Induction of mammary gland hyperplasia and carcinomas in transgenic mice expressing human cyclin E. Mol Cell Biol. 1997;17(1):453-9. https://doi.org/10.1128/MCB.17.1.453

19. Keyomarsi K, Pardee AB. Redundant cyclin overexpression and gene amplification in breast cancer cells. Proc Natl Acad Sci U S A. 1993;90(3):1112-6. https://doi.org/10.1073/pnas.90.3.1112 PMID:430082 PMCID:PMC45821
20. Wei CY, Tan QX, Zhu X, Qin QH, Zhu FB, Mo $\mathrm{QG}$, et al. Expression of CDKN1A/p21 and TGFBR2 in breast cancer and their prognostic significance. Int J Clin Exp Pathol. 2015;8(11):1461929. PMID:26823785 PMCID:PMC4713571

21. Han SH, Park KM, Bae BN, Ryu SY, KimKH, Kim $\mathrm{HJ}$, et al. Interrelation of Cyclin D1, Cyclin E, and p27Kip1 Expression on Tissue Arrays of Breast Cancer. Cancer Res Treat. 2002;34(5):388-93. https://doi.org/10.4143/crt.2002.34.5.388 PMID:26680892

22. Oh YL, Choi JS, Song SY, Ko YH, Han BK, Nam SJ, et al. Expression of p21Waf1, p27Kip1 and cyclin D1 proteins in breast ductal carcinoma in situ: Relation with clinicopathologic characteristics and with p53 expression and estrogen receptor status. Pathol Int. 2001;51(2):94-9. https://doi.org/10.1046/j.1440-1827.2001.01173.x

23. O'Lone R, Frith MC, Karlsson EK, Hansen U. Genomic targets of nuclear estrogen receptors. Mol Endocrinol. 2004;18(8):1859-75.https://doi. org/10.1210/me.2003-0044 PMID:15031323

24. Hermeking H, Funk JO, Reichert M, Ellwart JW, Eick D. Abrogation of p53-induced cell cycle arrest by c-Myc: evidence for an inhibitor of p21WAF1/CIP1/SDI1. Oncogene. 1995;11(7):1409-15. PMID:7478565

25. Anim JT, John B, Abdulsathar SS, Prasad A, Saji T, Akhtar N, et al. Relationship between the expression of various markers and prognostic factors in breast cancer. Acta histochemica. 2005;107(2):87-93. https://doi.org/10.1016/j.acthis.2005.01.002 PMID:15950051

26. Luhtala S, Staff S, Tanner M, Isola J. Cyclin E amplification, over-expression, and relapse-free survival in HER-2-positive primary breast cancer. Tumour Biol. 2016;37(7):9813-23. https://doi.org/10.1007/s 13277-016-4870-z PMID:26810187

27. Inwald EC, Klinkhammer-Schalke M, Hofstadter F, Zeman F, Koller M, Gerstenhauer $\mathrm{M}$, et al. $\mathrm{Ki}-67$ is a prognostic parameter in breast cancer patients: results of a large population-based cohort of a cancer registry. Breast Cancer Res Treat. 2013;139(2):539-52. https://doi.org/10.1007/s 10549-013-2560-8 PMID:23674192 PMCID:PMC3669503

28. Wong H, Lau S, Cheung P, Wong TT, Parker A, Yau T, et al. Lobular breast cancers lack the inverse relationship between ER/PR status and cell growth rate characteristic of ductal cancers in two independent patient cohorts: implications for tumor biology and adjuvant therapy. BMC cancer. 2014;14:826. https://doi.org/10.1186/1471-2407-14-826 PMID:25385074 PMCID:PMC4236427

29. Zheng WQ, Zheng JM, Ma R, Meng FF, Ni CR. 
Relationship between levels of Skp2 and P27 in breast carcinomas and possible role of Skp2 as targeted therapy. Steroids. 2005;70(11):7704.https://doi.org/10.1016/j.steroids.2005.04.012 PMID:16024059

30. Mirchandani D, Roses DF, Inghirami G, Zeleniuch-Jacquotte A, Cangiarella J, Guth A, et al. Loss of p27KIP1 expression in fully-staged node-negative breast cancer: association with lack of hormone receptors in $\mathrm{T} 1 \mathrm{a} / \mathrm{b}$, but not T1c infiltrative ductal carcinoma. Anticancer research. 2011;31(12):4401-5. PMID:22199306 PMCID:PMC3339028

31. Niu D, Wang G, Wang X. Up-regulation of cyclin $\mathrm{E}$ in breast cancer via estrogen receptor pathway. Int J Clin Exp Med. 2015;8(1):910-5. PMID:25785074 PMCID:PMC4358529

32. Gohring UJ, Bersch A, Becker M, Neuhaus W, Schondorf T. p21(waf) correlates with DNA replication but not with prognosis in invasive breast cancer. J Clin Pathol. 2001;54(11):866-70. PMID:11684722 PMCID:PMC1731310

33. Thor $\mathrm{AD}$, Liu S, Moore $\mathrm{DH}$, 2nd, Edgerton SM. Comparison of mitotic index, in vitro bromodeoxyuridine labeling, and MIB-1 assays to quantitate proliferation in breast cancer. J Clin Oncol. 1999;17(2):470-7. https://doi.org/10.1200/JCO.1999.17.2.470 PMID:10080587

34. Iacopetta B, Grieu F, Powell B, Soong R, McCaul K, Seshadri R. Analysis of p53 gene mutation by polymerase chain reaction-single strand conformation polymorphism provides independent prognostic information in node-negative breast cancer. Clin Cancer Res. 1998;4(7):1597602. PMID: 9676832

35. Weikel W, Beck T, Mitze M, Knapstein PG. Immunohistochemical evaluation of growth fractions in human breast cancers using monoclonal antibody Ki-67. Breast Cancer Res Treat. 1991;18(3):149-54. https://doi.org/10.1007/BF01990030 PMID: 1756257

36. Gaglia P, Bernardi A, Venesio $T$, Caldarola B, Lauro D, Cappa AP, et al. Cell proliferation of breast cancer evaluated by anti-BrdU and anti-Ki-67 antibodies: its prognostic value on short-term recurrences. Eur J Cancer. 1993;29A(11):1509-13. https://doi.org/10.1016/0959-8049(93)90284-M

37. Barbareschi $\mathrm{M}$, van Tinteren $\mathrm{H}$, Mauri FA, Veronese $\mathrm{S}$, Peterse $\mathrm{H}$, Maisonneuve $\mathrm{P}$, et al. p27(kip1) expression in breast carcinomas: an immunohistochemical study on 512 patients with long-term follow-up. Int $\mathrm{J}$ Cancer. 2000;89(3):236-41.

38. Leivonen $\mathrm{M}$, Nordling $\mathrm{S}$, Lundin $\mathrm{J}$, von Boguslawski K, Haglund C. p27 expression correlates with short-term, but not with long-term prognosis in breast cancer. Breast Cancer Res Treat. 2001;67(1):15-22. https://doi.org/10.1023/A:1010623326118 PMID:11518462

39. Barnes A, Pinder SE, Bell JA, Paish EC, Wencyk PM, Robertson JF, et al. Expression of p27kip1 in breast cancer and its prognostic significance. J Pathol. 2003;201(3):451-9. https://doi.org/10.1002/path.1464 PMID: 14595757

40. Lau R, Grimson R, Sansome C, Tornos C, Moll UM. Low levels of cell cycle inhibitor p27kip1 combined with high levels of Ki-67 predict shortened disease-free survival in T1 and T2 invasive breast carcinomas. Int J Oncol. 2001;18(1):1723. https://doi.org/10.3892/ijo.18.1.17

41. Caffo O, Doglioni C, Veronese S, Bonzanini M, Marchetti A, Buttitta F, et al. Prognostic value of p21(WAF1) and p53 expression in breast carcinoma: an immunohistochemical study in 261 patients with long-term follow-up. Clin Cancer Res. 1996;2(9):1591-9. https://doi.org/10.1016/0959-8049(96)84269-9

42. Diab SG, Yu YY, Hilsenbeck SG, Allred DC, Elledge RM. WAF1/CIP1 protein expression in human breast tumors. Breast Cancer Res Treat. 1997;43(2):99-103. https://doi.org/10.1023/A:1005752829260 PMID:9131264

43. Mathoulin-Portier MP, Viens P, Cowen D, Bertucci F, Houvenaeghel G, Geneix J, et al. Prognostic value of simultaneous expression of $\mathrm{p} 21$ and $\mathrm{mdm} 2$ in breast carcinomas treated by adjuvant chemotherapy with antracyclin. Oncol Rep. 2000;7(3):675-80. https://doi.org/10.3892/or.7.3.675

44. Thor AD, Liu S, Moore DH, 2nd, Shi Q, Edgerton SM. p(21WAF1/CIP1) expression in breast cancers: associations with p53 and outcome. Breast Cancer Res Treat. 2000;61(1):33-43.https://doi.or g/10.1023/A:1006455526894 PMID:10930088

45. Ceccarelli C, Santini D, Chieco P, Lanciotti C, Taffurelli M, Paladini G, et al. Quantitative p21(waf-1)/p53 immunohistochemical analysis defines groups of primary invasive breast carcinomas with different prognostic indicators. Int $\mathrm{J}$ Cancer. 2001;95(2):128-34.

46. Pellikainen MJ, Pekola TT, Ropponen KM, Kataja VV, Kellokoski JK, Eskelinen MJ, et al. p21WAF1 expressionininvasive breastcancerand its association with $\mathrm{p} 53, \mathrm{AP}-2$, cell proliferation, and prognosis. J Clin Pathol. 2003;56(3):214-20. https://doi.org/10.1136/jep.56.3.214

47. Hwang TS, Han HS, Hong YC, Lee HJ, Paik NS. Prognostic value of combined analysis of cyclin D1 and estrogen receptor status in breast cancer patients. Pathol Int. 2003;53(2):74-80. https://doi.org/10.1046/j.1440-1827.2003.01441.x PMID:12588434 
48. Michalides $\mathrm{R}$, Hageman $\mathrm{P}$, van Tinteren $\mathrm{H}$, Houben L, Wientjens E, Klompmaker R, et al. A clinicopathological study on overexpression of cyclin D1 and of p53 in a series of 248 patients with operable breast cancer. $\mathrm{Br} J$ Cancer. 1996;73(6):728-34. PMID:8611372 PMCID:PMC2074376

49. van Diest PJ, Michalides RJ, Jannink L, van der Valk P, Peterse HL, de Jong JS, et al. Cyclin D1 expression in invasive breast cancer. Correlations and prognostic value. Am J Pathol. 1997;150(2):705-11. PMID:9033283 PMCID:PMC1858273

50. Kenny FS, Hui R, Musgrove EA, Gee JM, Blamey RW, Nicholson RI, et al. Overexpression of cyclin D1 messenger RNA predicts for poor prognosis in estrogen receptor-positive breast cancer. Clin Cancer Res. 1999;5(8):206976. PMID: 10473088

51. Umekita Y, Ohi Y, Sagara Y, Yoshida H. Overexpression of cyclinD1 predicts for poor prognosis in estrogen receptor-negative breast cancer patients. Int J Cancer. 2002;98(3):415-8. https://doi.org/10.1002/ijc.10151 PMID:11920593

52. Nielsen NH, Arnerlov C, Emdin SO, Landberg G. Cyclin E overexpression, a negative prognostic factor in breast cancer with strong correlation to oestrogen receptor status. Br J Cancer. 1996;74(6):874-80. https://doi.org/10.1038/bjc.1996.451 PMID:8826852 PMCID:PMC2074748

53. Donnellan R, Kleinschmidt I, Chetty R. Cyclin $\mathrm{E}$ immunoexpression in breast ductal carcinoma: pathologic correlations and prognostic implications. Hum Pathol. 2001;32(1):89-94. https://doi.org/10.1053/hupa.2001.21141 PMID: 11172300

54. Span PN, Tjan-Heijnen VC, Manders P, Beex LV, Sweep CG. Cyclin-E is a strong predictor of endocrine therapy failure in human breast cancer. Oncogene. 2003;22(31):4898-904. https://doi.org/10.1038/sj.onc.1206818 PMID: 12894232

55. Gyorffy B, Lanczky A, Eklund AC, Denkert C, Budczies J, Li Q, et al. An online survival analysis tool to rapidly assess the effect of
Majidzadeh-A et al.

22,277 genes on breast cancer prognosis using microarray data of 1,809 patients. Breast Cancer Res Treat. 2010;123(3):725-31. PMID:20020197

56. Pils D, Bachmayr-Heyda A, Auer K, Svoboda M, Auner V, Hager G, et al. Cyclin E1 (CCNE1) as independent positive prognostic factor in advanced stage serous ovarian cancer patients - a study of the OVCAD consortium. Eur J Cancer. 2014;50(1):99-110. PMID:24176298

57. Cheng CW, Liu YF, Yu JC, Wang HW, Ding $\mathrm{SL}$, Hsiung $\mathrm{CN}$, et al. Prognostic significance of cyclin D1, beta-catenin, and MTA1 in patients with invasive ductal carcinoma of the breast. Ann Surg Oncol. 2012;19(13):4129-39. https://doi.org/10.1245/s10434-012-2541-x PMID:22864797

58. Guo LL, Gao P, Wu YG, Jian WC, Hao CY, Li H, et al. Alteration of cyclin D1 in Chinese patients with breast carcinoma and its correlation with Ki-67, pRb, and p53. Arch Med Res. 2007;38(8):846-52. https://doi.org/10.1016/j.arcmed.2007.06.004 PMID:17923265

59. Desmedt C, Ouriaghli FE, Durbecq V, Soree A, Colozza MA, Azambuja E, et al. Impact of cyclins $\mathrm{E}$, neutrophil elastase and proteinase 3 expression levels on clinical outcome in primary breast cancer patients. Int J Cancer. 2006;119(11):2539-45. https://doi.org/10.1002/ijc.22149 PMID:16929516

60. Sieuwerts AM, Look MP, Meijer-van Gelder ME, Timmermans M, Trapman AM, Garcia $\mathrm{RR}$, et al. Which cyclin E prevails as prognostic marker for breast cancer? Results from a retrospective study involving 635 lymph node-negative breast cancer patients. Clin Cancer Res. 2006;12(11 Pt 1):3319-28. PMID: 16740753

61. Somlo G, Chu P, Frankel P, Ye W, Groshen S, Doroshow JH, et al. Molecular profiling including epidermal growth factor receptor and p21 expression in high-risk breast cancer patients as indicators of outcome. Ann Oncol. 2008;19(11):1853-9. https://doi.org/10.1093/annonc/mdn 402 PMID:18641005 PMCID:PMC2733077 